\title{
Narratives Produced in Psychotherapy: a Challenge for Narratology
}

Les récits produits en psychothérapie : un défi pour la narratologie

\section{Françoise Revaz}

Translator. Société Coup de Puce Expansion

\section{(2) OpenEdition \\ Journals}

\section{Electronic version}

URL: https://journals.openedition.org/pratiques/10373

DOI: $10.4000 /$ pratiques. 10373

ISSN: 2425-2042

Publisher

Centre de recherche sur les médiations (CREM)

\section{Electronic reference}

Françoise Revaz, "Narratives Produced in Psychotherapy: a Challenge for Narratology", Pratiques

[Online], 181-182 | 2019, Online since 15 January 2021, connection on 05 September 2021. URL: http://journals.openedition.org/pratiques/10373 ; DOl: https://doi.org/10.4000/pratiques.10373

This text was automatically generated on 5 September 2021.

(c) Tous droits réservés 


\title{
Narratives Produced in Psychotherapy: a Challenge for Narratology
}

\author{
Les récits produits en psychothérapie : un défi pour la narratologie
}

\section{Françoise Revaz}

Translation : Société Coup de Puce Expansion

\begin{abstract}
We alone see our existence on Earth as a path endowed with meaning (and direction). An arc. A curve that takes us from birth to death. A shape that unfolds in time, with a beginning, a series of adventures, and an end. In other words, $a$ narrative. (Nancy Huston, 2008, p. 14)
\end{abstract}

1 From time immemorial, humans have told stories about themselves and the world, expressing their innate nature as homo fabulator. This can be seen in the countless forms of narrative expressed in the discourse of modern society. In addition to the various semiotic forms of narrativisation (oral, written, still or moving pictures), we can see an infinite diversity of narrative genres in different types of socio-discursive fields: economic, historical, legal, literary, media-related, medical, political, etc. ${ }^{1}$ The list seems endless and yet the theorisation of narrative has often been confined to a study of the most elaborate forms of written literature. In this paper, we will look at an original and complex narrative situation: the oral production of personal narratives during sessions of family psychotherapy. These particular narratives pose a challenge for narratology, which was initially built on narratives in Fiction or History, rather than on ordinary oral narratives. ${ }^{2}$ Given the specific institutional and interactional context of discussions between therapists and their patients, we could well query whether conventional narratology methods are appropriate for studying this type of corpus. The narratological tools forged primarily for written and monologic narratives, considered as finished products, cannot correctly transcribe the dynamics of a narrative production that is co-constructed through verbal interaction. In order to 
analyse these productions, therefore, we need to develop these classical approaches by exploring the new theoretical avenues opened by post-classical narratology. Let us make it clear from the outset that post-classical narratology does not function in opposition to classical narratology. Rather, it extends its achievements by drawing upon concepts and methods from a range of disciplines (cognitive sciences, for example) and by broadening its field of study to include other genres and forms: ${ }^{3}$

Post-classical narratology asks the same questions as classical narratology: what is a narrative (as opposed to a non-narrative)? What does narrative consist in? Also, what increases or diminishes narrative, what influences its nature and degree, or even what makes a narrative narratable? It also raises other questions about the relationship between narrative structure and semiotic form, their interaction with the encyclopaedia (knowledge of the world), the function and not just the functioning of narrative, the meaning of this or that narrative and not just the way in which any narrative conveys meaning, the dynamics of narration, narrative as a process or production and not simply as a product, the influence of context and means of expression, the role of the receiver, the history of narrative as much as its system, narratives in their diachrony as much as in their synchrony, and so on. (Prince, 2006, p. 2.)

2 I would say that the main contributions of post-classical narratology are the following. ${ }^{4}$ First and foremost, the realisation that narrative (even monologic and written) is an act of speech, and that, in order to analyse it, we must take account of the specific institutional and cultural context in which it was produced. Where classical narratology focused solely on the formal properties of the narrative text, its structure and content, post-classical narratology considers the various parameters of the narrative situation: the narrator and the narratee as "situated" ${ }^{5}$ persons the active processes of production and reception, and the function of the narrative. Another important contribution is the emphasis placed on the role of the reader and their interpretative activity. Where classical narratology began the process of analysis only after the narrative had been read (or heard) through to the end, considering it as a finished and completed product, the post-classical approaches give new importance to the interpretative path followed by the reader (or interlocutor) who, as the narrative unfolds, can anticipate possible scenarios and formulate hypotheses. ${ }^{6}$ In our corpus, the challenge will also be to take account of the polylogal nature of the narratives produced and to show how the various participants in a therapy session adapt what they say in the light of what has already been said.

\section{"Narrative" approaches in medicine}

3 Since the time of Hippocrates, doctors have always listened to their patients' history. And since the end of the 1960s, first in the United States and then in Europe, we have seen the development of a so-called "narrative" medicine, which purports to compensate for the increasingly technical aspects of the medical relationship by restoring the patient narrative to its central role. This approach aims not only to humanise the doctor-patient relationship, but also to take account of the theoretical assumption that a narrative way of thinking is better than a logical and scientific way of thinking for understanding people, their illnesses and their symptoms. ${ }^{7}$ We should also add an underlying postulate, now widely accepted, that our identity is made up of a collection of stories:

- the stories we tell ourselves about our lives; 
- the stories that people we know tell about us;

- the "model" stories (fictional or factual) that we were told as children or that we read and hear every day. ${ }^{8}$

In the psychiatric context, while the use of narrative seems unavoidable here too, we can also see a keen interest in "narrative therapy", a method developed in family therapies in the 1980s based on the work of social worker Michael White and psychotherapist David Epston (2003). In this type of medical approach, patient narratives are seen not simply as retrospective accounts of their experiences, but as factors that shape their lives and identities, and that therefore have the power to influence their future and create "another self":

The main point is that to narrate one's life is to create it. The imperfect words that I use to talk about myself create "another self". No one is entirely sure of what they are. When people talk about themselves, they discover - in the interstices of their words - this other self that they do not know, emerging from the imperfection of their words. In other words, we do not say who we are and then talk about ourselves; rather, it is by talking about ourselves that we come to be. [...]

When, as a caregiver, we listen to a patient talking about themselves, we are not just listening, but taking part in a catalytic act of creation. The caregiver gives the patient the opportunity to recreate themselves. Moreover, the illness itself often gives patients the opportunity to recreate their lives. When narrative is added, the creative potential is increased tenfold. (Jacques Quentin, 2014, p. 7-8.)

In short, the way in which patients talk about their lives will have an impact on the way they live it in the future. The therapist will therefore encourage the patient to produce new narratives in order to change the course of their lives. ${ }^{9}$ The fundamental observation taught by the various narrative approaches in medicine and psychiatry is that, by talking about ourselves, we can give our lives new meaning and new direction.

We could go even further and postulate that we are already living our lives in narrative mode since we form ourselves and live our lives as subjects of a story in progress. This is precisely the key idea behind phenomenological approaches to narrative. For example, the philosophers David Carr, Jean Greisch and Wilhelm Schapp ${ }^{10}$ reflect on the existence of a form of narrative that is constitutive of human life (an ontological narrative) and ask whether the real purpose served by our narrative models (stories read or heard since childhood) is rather to shape our everyday experience. They therefore defend the idea that stories "precede the states of things":

[Schapp puts forward] a paradoxical "epistemology" that seeks to overturn the conventional relationship between stories and the "state of things". While all the philosophical theories of the episteme start off from the assumption that the world exists independently of stories and that stories and narratives give rise to postulates that fix the states of things which, in turn, can become part of stories under certain conditions, Schapp believes that even from an "epistemological" standpoint, stories precede the states of things! [...] ...] We must therefore abandon the convenient belief that before "appearing" in a story, things already have an independent, objective and autonomous meaning, to which a subjective meaning is added simply by reason of their connection with a story. (Greisch, 2005, pp. 2 and 5.)

Based on a phenomenological approach, the narratives of our culture would be seen as the "templates" of our experience, as it were, while social and individual realities would already be structured from a narrative standpoint. 


\section{Telling stories in family psychotherapy: what is the right approach?}

8 Contrasting with the traditional psychoanalytic approach (individual, face-to-face with the therapist), the family therapies discussed here require the presence of several family members (parents, siblings, even grandparents) ${ }^{11}$. The choice of family members invited to take part depends of course on the type of family organisation: a family built around two parents, a "broken" family (with separated parents) or a "blended" family (with new partners for the parents, or even new siblings for the children). The psychoanalyst Pierre Benghozi (2013, p.18) describes this approach as follows: "Deciding to see the child from the outset in the presence of their parents and siblings presupposes an approach in which listening and evaluation are based not only on an individual analysis of behaviours and symptoms, but also on the current psychic economy of the entire family group."

9 The basic premise is that the psychological and behavioural disorders of a given family member are often symptomatic of a broader dysfunction affecting the entire group, thus requiring a collective approach. In this sense, "embracing the psychic economy of the family group" involves focusing not only on what is said by the family member with a psychic disorder, but also listening to all the other voices. The objective is for a new family "narrative" to emerge from the fragments of narrative expressed by the various participants over the course of the sessions. On this point, Benghozi talks about group "neonarrative". It is specifically the purpose of this emerging neonarrative to provide the family with an alternative for change, i.e. the possibility of a new life scenario.

When conducting a family therapy, the therapist sees each speaker as a "mouthpiece" for the family story or, to take a suitable orchestral metaphor, as an "instrument in a symphony", a symphony in which the therapist will also take part. So it is not a typical life story that will be produced, but snippets of stories from the interwoven lives of the family group. Here, we touch on one of the first complexities arising from the narratives produced in family therapy, a complexity that is further compounded by the fact that the group or family neonarrative does not translate into a concrete narrative that can suddenly be told at the end of therapy. Rather, the term refers to a new life project or a redefined narrative identity, in short, to a real-life neonarrative. ${ }^{12}$ Let's return for the moment to the actual narratives recounted during therapy and see what they consist of.

\section{Narrative in family psychotherapy: a specific type of production}

\section{A fragmented narrative}

11 Identifying specific narrative "moments" in therapy sessions is not easy. It quickly becomes apparent that patients produce relatively few standardised complete and independent narratives. Rather, they produce outlines or snippets of narrative whose main characteristic is to be interwoven into the verbal exchange with the therapist rather than standing alone. Moreover, these fragments may be repeated during the session, either by the same family member or by somebody else, and may also be 
expanded, corrected or reformulated. ${ }^{13}$ It is not uncommon for one of the participants to feel the need to go back over a narrated event in order to add a new twist or even a different ending, or for the therapist to reopen the discussion by asking one of the patients to add to their narrative. To study these fragments of narrative, it is therefore necessary to consider their dynamic insertion in the interview, as well as any possible changes over time.

\section{An inchoate narrative}

12 A second observation is that these narratives and snippets of narrative are often left hanging. In this respect, it is difficult to apply the concepts of "closure" or "entirety", often used to define narrative. For example, although theories relating to life stories describe narrators as adopting a distanced, retrospective stance, looking back at a past and completed episode in their lives and recounting it in hindsight, this is rarely the case in therapeutic interviews. Here, we are touching upon the non-definitive nature of the narratives produced during psychoanalysis, theorised by Ricœur $(1983$, p. 114) as "inchoate narrative":

The analysand brings the psychoanalyst fragments of past experiences, dreams, "primal scenes", and conflictual episodes. We could say with good reason that the role of the analyst is to piece together these scattered fragments to produce a narrative that is both more bearable and more intelligible. [...] - This narrative interpretation of psychoanalytic theory implies that a life story is based on untold and repressed stories, moving towards actual stories that the subject can take up and hold as constitutive of their personal identity.

13 By asserting that "a life story is based on untold and repressed stories, moving towards actual stories that the subject can take up and hold as constitutive of their personal identity", Ricœur is faithful to the theory of phenomenology, showing that it is through narrative activity that experience gains meaning and therefore that personal experience already has a "pre-narrative" structure. In this sense, there is clearly a continuity between the inchoate narrative of life and the non-definitive and open narrative of the actual stories produced in therapy. Benghozi's family therapies start from fragments of actual stories to move towards what he considers to be a potentially new and different family macro-narrative: a real-life experiential group neonarrative that is more comfortable for the whole family and that may pave the way for new actual narratives. I see this narrative "cascade" as a second factor in the complexity of the narratives produced in therapy.

\section{A narrative in serial form}

14 The third observation is that the narratives (or narrative fragments) produced are part of larger units: on the one hand, the unit of regular consultation and, on the other, the unit of therapy, i.e. the sum of the discursive interactions taking place session after session. The family narrative discussed by Benghozi is actually an experiential macronarrative of the future, emerging gradually from all the micro-narratives and narrative fragments deposited over the course of the sessions. We can thereby see similarities with the serialisation process in which the conclusion of the story is always pushed back to the "next episode"..$^{14}$ In the specific case of family therapies, which are part of a continuously monitored process, the narratives or fragments of narrative produced 
during the course of the sessions are often simply an episode in the macro-narrative of the family, to be (re)built and continued.

\section{What are the questions? What is the challenge?}

Narratives produced in a therapeutic setting are usually categorised as "self" or "life" narratives, in all cases relating to autobiographical narratives. In The Autobiographical Pact, the widely known work published in 1975, Philippe Lejeune defines these narratives as follows: "a retrospective account in prose that a real person makes of his own existence stressing his individual life and especially the history of his personality" (1975, p. 14). Inherent in the autobiographical pact is the narrator's guarantee that the story is true. In addition to these criteria of retrospection and truthfulness, the life story (told orally in a session) is generally regarded as a "conversational" narrative, i.e. a monologic narrative that is part of a dialogue. ${ }^{15}$ Based on a corpus of around ten filmed and recorded family therapy sessions, we will now challenge these preconceived ideas on self-narrative, taking the three questions below as our main thread:

- Are narratives (or narrative fragments) always retrospective?

- Are narratives (or narrative fragments) always true?

- Are narratives (or narrative fragments) always monologic?

\section{Are narratives always retrospective?}

The narrative fragments identified in the interviews challenge the assumption that narrators only adopt a distanced, retrospective stance, looking back at past and completed episodes in their lives and recounting them in hindsight. We can see that this is not the only possible stance. While it's true that patients regularly look back on past events, they also produce fragments of narrative about events in the future. As an example, we will look at a first extract.

This is an exchange between two people: a pregnant woman (PW) about to give birth and her therapist Pierre Benghozi (Therap.). This exchange is part of a therapy involving regular sessions with this pregnant woman, her two-year-old son, who has a slight mental disability, and her ex-husband, who is also the father of the young boy. The situation is complicated because the woman is carrying the child of a man who very quickly turned out to be her mother's lover. When this interview was recorded, the woman was living temporarily with her ex-husband for a few days each week so that he could look after their son while she was having the baby in hospital. At the beginning of the recording, the therapist is interested in finding out why the woman decided to move back in with her ex-husband.

Extract 1. A forward-looking narrative ${ }^{16}$

(1) Therap.: OK, so you'd rather take precautions... but at the same time, you're together for the moment mainly out of convenience because

(2) PW: of

(3) Therap.: $\underline{\text { so }}$

(4) PW: it's mainly for our little boy

(5) Therap.: $\underline{\text { so }}$

(6) PW: so that I don't end up, say, all on my own, having to, er

(7) Therap.: so that you don't have to rush to hospital

(8) PW: in an emergency because I've lost the plug and might have the baby at any time <yes> and if I can't get hold of his dad, I'm not going to take him with the 
(9) Therap.: who is

(10) PW: firefighters to the

(11) Therap.: who is er who is overseeing your er medical care for the birth say, all on my own". In the next turn (7), the therapist interrupts the patient's narrative and anticipates what she is about to say: "so that you don't have to rush to hospital". The suggestion is confirmed by the woman who says "in an emergency" at the same time as the therapist. This projection into a hypothetical future is underlined, in turn 6, by the verb "say" which indicates a supposition. The woman continues to talk about the possible scenario, returning in turn 8 to the hypothesis in which she is unable to reach her ex-husband ("if I can't get hold of his dad") and therefore has to go to the hospital alone with her son. Here, it is the verbal syntagm "if I can't" that introduces the hypothesis.. In turns 8 and 10, the inevitable but unwanted consequence of the possible scenario is expressed: "I'm not going to take him with the firefighters into" (implied: "into the maternity ward"). The reasons behind this minimal narrative are given in turn 8 where the pregnant woman mentions that she has "lost the plug" and might therefore "have the baby at any time". So in fact it was the imminence of the birth that prompted her to move back in with her ex-husband, in order to avoid the catastrophic scenario she talks about. This account of possible events, which is not updated, challenges what Matthias Aumüller (2007, p. 229) says in the collective work A Theory of Narrative: “Texts discussing everyday, repeated hypothetical, events [have] a low or non-existent level of eventfulness and cannot therefore be regarded as narrative texts, even if they deal with numerous events."

If we were to apply Aumüller's statement, we would need to set aside many narratives and narrative fragments that nevertheless play an important role in psychotherapeutic interviews. The narration of everyday or hypothetical events is common in family therapy, as we have just seen with the pregnant woman's narrative comments about her everyday concerns and her projections regarding the future. This observation raises the problem of tellability and questions one of the main postulates of narratology, namely that the narrative must represent an unpredictable or unusual development of an action (a deviation from the norm) and that the tellable aspect is "what creates an event in life, i.e., something that is out of the ordinary" (Baroni, 2005, p. 2). Although this is true in some narrative genres, it seems clear - in a medical 
psychiatric context and as part of a doctor-patient relationship - that the narratives produced are well suited to describing everyday life and routine. ${ }^{17}$

Returning to the question of retrospection raised at the beginning of the section, we can see that at the local level of a therapy session, many occurrences of forwardlooking narrative fragments may appear, often of a hypothetical nature. However, the family macro-narrative remains the overall level at which the forward-looking stance takes on the greatest importance, given that the narratives or narrative fragments produced during a session are often only one episode in a narrative that will be continued, as part of a process of serialisation in which the end of the story is always pushed back to the "next episode". At this macro level, we have the future family narrative, which will be built during the course of the sessions. There is indeed a forward-looking aspect here (concerning a narrative that is as yet untold, virtual and hypothetical), bringing us back to the concept of inchoate narrative.

\section{Are narratives always true?}

The problem of the truth in narrative is a complex and much-debated issue. In social sciences, in sociology for example, a life story claims to tell a true story. However, the fact that we cannot guarantee the truthfulness of what narrators say in their autobiographies often robs the biographical method of credibility. Conversely, in a psychoanalytical context, what seems to be decisive is not so much the truthfulness of what is told but its meaning for the analyst. ${ }^{18}$ On the subject of narrative in healthcare relationships, Quentin $(2014$, p. 56) even comes to the conclusion that "the true narrative is not the one conveying information that we can corroborate, but rather the one that leads us towards the enigma of existence". Looking beyond this debate between researchers with widely varying expectations, there is generally an expectation in practice for the self-narrative to be true, or at least to offer an insight into a certain truth. However, we can see that self-narrative can never be a simple, objective and transparent account of events experienced (an exact transfer of reality). It is always a reconstruction, in which the narrator selects the facts that they consider to be most relevant or most salient, thus giving the autobiographical narrative its eminently partial and biased slant. Moreover, a number of obstacles exist between the actual experience of an event by the narrator and its narration: a forgotten or distorted memory, or an emotion that suddenly rises to the surface and acts as a screen. On the subject of memory, for example, Huston (2008, p. 25) says: "Our memory is a fiction. This does not mean that it is false, but that, without being asked, it spends its time ordering, associating, articulating, selecting, excluding and forgetting, in other words, building or fabulating".

In view of these obstacles (failing memory, forgetfulness, etc.), the self-narrative is often considered as a "subjective reconstruction that in the final analysis has no connection with the real-life experience" (Bertaux, 1997, p. 36).

In the anecdote below, the philosopher Francis Kaplan (2001, pp. 71-72) clearly shows the extent to which the narrative can "distort real life depending on the emotion inspired":

[...] while ski-ing down the Grands Montets, I wanted to weave past a wall. I missed the turn because of the ice, fell over and found myself hanging upside down by my boots. These were still attached to my skis, which were sticking upright in the snow. When I thought about this adventure, it was clear to me that the wall formed 
a particularly steep slope. I returned to the same place a few years later and saw the wall again. The slope was actually very slight, but the emotion aroused by the height of the mountain where I fell - the summit of the Grands Montets, at 3,300 metres - the howling wind, the icy snow, the fall itself, the position in which I found myself, the difficulty of getting up, and the desire to justify my fall, had greatly increased the gradient of the slope.

second turn of speaking, she simply says that her brother is dead, in response to the therapist's observation. The therapist knows full well that it's not true (as illustrated by his laughter and his remark further on: "what are you saying?"), but he goes along with $\mathrm{M}^{*}$ by asking her what she did with her brother. In turn $6, \mathrm{M}^{*}$ sets out a first minimal narrative sequence with an evaluative proposal ("it's not like it matters") followed by three other proposals, with the first repeating the fact of her brother's death and the other two providing the causal sequence of the event: "he tripped" (cause) THEREFORE "he's dead" (consequence). After a brief pause, the therapist acknowledges what she says by "right", and $\mathrm{M}^{*}$ carries on with a second minimal narrative explaining the course of events: "he didn't tidy his room" (initial situation),

(2) $\mathrm{M}^{*}$ : yeah, he's dead

(3) Therap.: he's dead (laughter) poor Ma*

(4) $\mathrm{M}^{*}$ : yeah because

(5) Therap.: what did you do with him?

(6) $M^{*}$ : it's not like it matters, he's dead, he tripped, he's dead. <right> well, he didn't tidy his room and he caught his no he impaled himself on his Playmobil castle when he was playing with it and then he died.

(7) Therap.: (in low voice) what are you saying?

(8) $M^{*}$ : but I swear it's true, that's why he's not here because XXX should be here but (makes noise with mouth) as he's dead, he's not here. (sigh) .. that's the way it is (9) Therap.: he tripped/

(10) $\mathrm{M}^{*}$ : he impaled himself on his Playmobil ship and then well, he just died because the mast went through his vital organs and then, well, that was it... but we hid him under the bed you know, we have to keep it quiet, everybody thinks he's still alive. We hid him under the bed, that's why it pongs a bit (smiles) 
"he impaled himself on his Playmobil castle" (key event) "and then he died" (end). After expressing doubts and listening to $\mathrm{M}^{*}$ 's claim to be telling the truth, the therapist returns to the supposed cause of death by repeating "he tripped" in an interrogative tone of voice. $\mathrm{M}^{*}$ then suggests another version made up of two proposals: "he impaled himself on his Playmobil ship" (key event) "and then he died" (end). She adds "because the mast went through his vital organs" to make her brother's death seem more plausible. ${ }^{20}$

In this discussion, the therapist immediately understands that by talking about the supposed death of her brother in a casual, offhand way, $\mathrm{M}^{*}$ is unconsciously expressing an issue with death and grief, protecting herself from something that is too hard to bear. ${ }^{21}$ During this session, we learn that her father committed suicide in circumstances that are unclear. But $\mathrm{M}^{*}$ will refuse to talk about her father's death and makes a mockery of anything relating to this tragic event.

\section{Are narratives always monologic?}

Researchers working on so-called "conversational" narratives, i.e. narratives produced by a speaker in the context of a conversation or interview, generally analyse these narratives by considering them independently. This type of analysis is possible only because these are usually monologic narratives integrated in a dialogical exchange. It is more complicated for the narratives produced in family therapy, given their strongly "polylogal" nature. These narratives are the result of a co-construction involving all the participants who, together, provide information, interpret what the others say and, as a result, continuously adjust what they themselves say in the linearity and temporality of the consultation. These mechanisms of co-construction can be observed not only in the dialogue between the therapist and one (or more) patient(s), but also in the dialogue between patients. In fact, a consultation generally involves a range of discussions between the therapist and a given speaker and "group" conversations in which each member of the family can add details to what the others say. In all cases, the discussion unfolds freely in a context where the therapist asks relatively few questions. In an attempt to enter as much as possible into what he refers to as the "narrative play" of participants, the therapist will encourage each person to continue what they have started to say, using a variety of techniques (repeating and rephrasing). Through this active participation by the therapist in the group narrative, the narratives become polylogal. This makes it possible to further develop the conversational approach of the narrative by taking account of the fact that verbal exchanges are not simply a juxtaposition of successive statements, but a co-constructed text, as explained by Catherine Kerbrat-Orecchioni (1986, p. 14):

"The telegraph metaphor is replaced by that of an orchestra, but an orchestra with no conductor and no score, in which each musician picks up the tune played by the others. Instead of viewing dialogue as a discourse produced successively and alternately by L1 and L2, it is the text of the discussion in its entirety that must be considered as jointly co-constructed by the interacting parties, following an infinite number of explicit or implicit micro-"negotiations", relating to all the constituent parts of the interaction (form, structure, content, "identities", places, etc.)."

Benghozi (2013, p. 22) also uses the orchestral metaphor, emphasising that the therapist does not only listen to the stories told by various family members, but can also take part in their production: 
Taking the metaphor of the music played by the family, the therapist is positioned not only outside the score but also inside it, taking part in the co-construction of the soundscape. The therapist is a conductor [...] but also an instrumentalist, a creator of what emerges from the therapeutic space. her mother (Mother). They're telling the therapist about an incident (true this time) that occurred the previous year, when they were travelling with the younger brother $\mathrm{Ma}^{*}$ to their father's funeral. Before the passage quoted, a long discussion took place between the therapist (Therap.) and the mother. The mother talked about the circumstances of her ex-husband's suicide, going into detail about how the funeral was organised and, last, the long drive across France with her children to attend the funeral, travelling in a friend's car.

Extract 3 A narrative co-constructed by two patients

(1) Therap.: you were saying: just before: XXX

2) Mother: well, the kids $<\left(M^{*}\right.$ laughs $)>$ were going wild in the car

(3) $\mathrm{M}^{*}$ : yeah I'll explain (laughs)

(4) Mother: but we weren't yet er well

(5) $M^{*}$ : right I'll explain right it isn't XXX either, I'll explain what happened is that the friend of mum's who picked us up, we didn't have a car as we'd come by plane, she had a car, yeah, a car you see, and the floor of the car, well a p- a part of the car that was loose and starting to fall off and $\mathrm{Ma}^{*}$ and me were just cracking up, like the bottom of the car has dropped out (laughs)

(6) Mother: they thought that the car had just come out of the garage ( $\mathrm{M}^{*}$ laughs) and that they'd put er two of the bolts back on wrong and suddenly on the motorway ( $M^{*}$ laughs) bang so for them it was very funny ( $M^{*}$ laughs) er let's say it was a bit of an adventure.

At first glance, the narratives of $\mathrm{M}^{*}$ and her mother may appear to be simply juxtaposed (based on the same event experienced together, with mother and daughter each offering their version, focusing on slightly different salient points). However, these two narratives are indeed the result of a co-construction, since the mother relies on her daughter's account to tell her own story. In the first turn of speaking, the therapist asks the mother to continue what she mentioned two turns previously, about her children laughing before the funeral. The mother begins her story by describing the atmosphere in the car ("the kids were going wild in the car"), but she is immediately interrupted by her daughter who wants to take control of the narrative ("yeah I'll explain"). Despite an attempt by her mother to continue, the teenager firmly establishes her version of events in turn 5. It is only after she has finished that her mother completes the story by talking about the cause of the incident on the motorway. In this way, we can see both the complementarity of the two narratives and their differences.

The teenager focuses on the fact that a part was loose under the car, describing this incident as the key event in her narrative. She ends by describing her own reaction and that of her brother ("Ma* and me were just cracking up"). In this way, $\mathrm{M}^{*}$ provides a subjective account of events clearly seeking to underline this moment of shared laughter with her brother. At the same time, the mother elaborates on what her daughter says in order to provide a more objective account and to explain why a part of 
the car fell off. To do this, she focuses on the work of the mechanics and the key event in her story is a mistake by the garage ("they'd put two of the bolts back on wrong"). She immediately goes on to explain the consequences ("suddenly on the motorway, bang"). It is worth noting here that if the mother is able to summarise the incident on the motorway with a single onomatopoeia - "bang" - it is because her daughter has already provided the details. Finally, the mother ends with an evaluative comment ("for them it was very funny, let's say it was a bit of an adventure"). This allows her to link the event to what she discussed earlier, i.e. the fact that her children were laughing in the car on the way to their father's funeral.

In the extract below, we can see a narrative co-constructed by two therapists and the members of a family. Present for the session are a very young mother (Mother), her three-year-old son $\left(\mathrm{Cl}^{*}\right)$, the therapist (Therap.) and his co-therapist (Co-ther.). During the recording, the child was initially drawing at a table while the adults were engaged in discussion, but he suddenly started talking about an accident he had with his bike a few days previously.

Extract 4 A narrative co-constructed by all the participants

(1) $\mathrm{Cl}^{*}$ : I fell off (he pulls up his sleeve to show his elbow) look <Therap. oh:>

(2) Co-ther.: tsss: where did you fall off?

(3) $\mathrm{Cl}^{*}$ : er off (sweeping arm movements) er fell off my bike

(4) Co-ther.: I bet that hurt

(5) Therap.: oh, so you fell off your bike

(6) Mother: and with mum, mum was there too, you didn't say, it wasn't just $\mathrm{Cl}^{*}$

(7) $\mathrm{Cl}^{*}$ : yes, it was mum

(8) Mother: and why, because $\mathrm{Cl}^{*}$ didn't obey

(9) $\mathrm{Cl}^{*}$ : oby and now I have to be careful

(10) Therap.: so you do

(11) Co-ther.: so mum fell off too

(12) Therap.: so mum hurt herself too

(13) Mother: yeah XX

(14) $\mathrm{Cl}^{*}$ : her finger

(15) Therap.: she hurt her finger

(16) Mother: XXX

(17) Therap.: because you fell off your bike, is that right/

(18) Mother: no, actually, he's used to going on holiday with my parents to friends in $A^{*}<$ yeah> it's hilly and there's the forest <yeah>

(19) $\mathrm{Cl}^{*}$ : afterwards you XXX

(20) Mother: my dad got his bike out and I er

(21) $\mathrm{Cl}^{*}$ : you see, got hurt got hurt

(22) Mother: I was a bit behind him and I saw him tumble off so I ran <yes> and I tried to catch him but in the hills well there are always tumbles <well $>$ I tried to protect him and that's how <yeah> I cut my finger but it's OK now hardly anything.

In this extract, the narrative advances in four successive phases. In the first phase, the child says that he fell over and shows his injured elbow to the therapist who acknowledges the fact while his co-therapist asks a question ("where did you fall off?"). $\mathrm{Cl}^{*}$ completes his first statement ("I fell off") by describing the circumstances in turn 3: "fell off my bike". In turn 4, the co-therapist comments on the incident ("I bet that hurt"). The therapist goes on to summarise the child's comments ("so you fell off your bike"). Then in turn 6 , the mother adds a new piece of information to her son's story ("and mum was there too"), pointing out that he forgot to mention it ("you didn't say"). We can consider this turn of speaking as a coenunciation by "addition" 22 given that the mother's words are added to what her son says by the conjunction "and", the result 
being: "off your bike"' "AND with mum too"). $\mathrm{Cl}^{*}$ confirms by rephrasing "yes, it was mum". In turn 8 , the mother adds to the narrative by explaining why she fell off too ("because $\mathrm{Cl}^{*}$ didn't obey", pausing between "didn't" and "obey". In turn 9, the child repeats the word "obey" emphasised by his mother, mispronouncing it slightly ("oby"), and adding a moral to the story ("and now I have to be careful"), a new coenunciation by addition. Finally, the therapist confirms what the child says and concludes this part of the narrative with a conclusive "so you do". In the third phase, the narrative is resumed, picking up the information provided by the mother in turn 6 suggesting that she fell off her bike too. Note here that both therapists repeat this information from the child's viewpoint since they talk about the mother as "mum". $\mathrm{Cl}^{*}$ then adds that his mother hurt "her finger". This information is picked up by the therapist who concludes this phase in turn 15 with "she hurt her finger". In the final phase, the psychotherapist asks Cl*'s mother to clarify her account ("but it was because you fell off your bike, is that it?"). Once again, the connector (in this case: "but") allows the speaker to pick up what has already been said in order to continue the narrative. The mother then takes over and tries to tell the whole story of the accident, interrupted twice by her son who wants to show the therapist the plaster that his mother is wearing on her finger following her fall. From turn 18, the therapist interrupts only to punctuate the young mother's story with a series of backchannel signals ${ }^{23}$ ("yeah", "yeah", "yes", "OK" and "oh OK"), showing that he is listening carefully, as these verbal signals appear to occur at key moments in the narrative process.

The structure of this narrative can be summarised as follows:

- framework: he's used to going on holiday with my parents to friends in $A^{*}$, it's hilly and there's the forest (turn 18)

- Initial situation: my dad got his bike out and I was er a bit behind him (turns 20 and 22)

- key event: and I saw him tumble off (turn 22)

- reaction: so I ran I tried to catch him (turn 22)

- key event (cont'd): but in the hills well there are always tumbles (turn 22)

- reaction (cont'd): I wanted to protect him (turn 22)

- conclusion: that's how I cut my finger (turn 22)

- end: but it's OK now hardly anything (turn 22)

Note the many connectors and organisers punctuating the narrative: "and", "so", "but" and "now". In this long extract, we can see the extent to which, in the turns of speaking, each participant adds to what has already been said, resulting in a narrative of the accident that is co-constructed by all the participants present.

\section{Conclusion}

By taking narratives produced during psychotherapeutic sessions as the object of study, we were able to observe the extent to which the corpus of reference influences the researcher's theoretical horizon and their methods of analysis. ${ }^{24}$ The specific nature of the narrative and narrative fragments produced in family therapy requires a radical change of perspective compared to the traditional structural analysis of, for example, of a story or novel. In this specific context, the aim is to consider narrative as part of a more dynamic approach and to focus not only on the finished product but also on the narrative process with its snippets, hesitations and words left hanging. As we have seen in the various analyses set out here, the narratives produced by patients tend to be 
fragmented, open-ended and non-definitive. Over the course of the sessions, the same events are repeated and retold, with family members adding details, rectifying a previous version, or even contradicting it. This characteristic of the narratives produced in therapy requires close attention to everything that is said, even if it is only the beginning or a fragment of a story. Another element to be taken into consideration is the fundamentally polylogal character of the narratives produced. Very often, the personal experiences recounted by one family member are recounted concurrently by other family members, each one helping to take the narrative forward. In this multivoiced production, the therapist's voice is also frequently heard, encouraging the patients to continue and complete their narrative. In short, to fully describe the wealth and complexity of this body of work, it seems essential, on the one hand, to show how the narratives emerge step-by-step over the course of the sessions, and on the other, to describe as accurately as possible the way in which these stories are co-constructed by multiple voices.

\section{BIBLIOGRAPHY}

ADAM, J.-M. (2011). Genres de récits. Narrativité et généricité des textes. Louvain-la-Neuve:

L'Harmattan-Academia.

AUMÜLLER, M. (2007). “Narratif, descriptif”. In: Pier, J. (ed.), Théorie du récit. L'apport de la recherche allemande. Villeneuve d'Ascq: Presses universitaires du Septentrion, pp. 227-244.

BARONI, R. (2005). “Récit de passion et passion du récit”. Vox Poetica. Online: http://www.voxpoetica.org/t/pas/baronipsnr.html.

BARONI, R. \& REVAZ, F. (eds) (2016). Narrative Sequence in Contemporary Narratology. Columbus: The Ohio State University Press.

BENGHOZI, P. (2013). “Contenant malléable, cadre, dispositifs et nouvelles configurations du "faire famille" : la fonction accueil trampolino". Revue de psychothérapie psychanalytique de groupe 60 , pp. 7-34. Online: https://www.cairn.info/revue-de-psychotherapie-psychanalytique-degroupe-2013-1-page-7.htm.

BERTAUX, D. (1997). Les Récits de vie. Perspective ethnosociologique. Paris: Nathan.

BRUNER, J. (2002). Pourquoi nous racontons-nous des histoires? (Why do we tell stories?) Translated from the English by Y. Bonin. Paris: Retz.

GREISCH, J. (2005) [1990]. “Empêtrement et intrigue. Une phénoménologie pure de la narrativité est-elle concevable?”. Vox Poetica. Online: http://www.vox-poetica.org/t/pas/greisch.html.

HuSTON, N. (2008). L’Espèce fabulatrice. Arles: Actes Sud.

JEANNERET, T. (1999). La Coénonciation en français. Approches discursive, conversationnelle et syntaxique. Bern: Peter Lang.

KAFALENOS, E. (2006). Narrative Causalities. Columbus: The Ohio State University Press. 
KAPLAN, F. (2001). Des singes et des hommes. La frontière du langage. Paris: Fayard.

KERBRAT-ORECCHIONI, C. (1986). "Nouvelle communication" et "analyse conversationnelle" Langue française 70, pp. 7-25. Online: https://www.persee.fr/doc/lfr_0023-8368_1986_num_70_1_6368.

LAFOREST, M. (1996). “De la manière d'écouter les histoires : la part du narrataire”. In: Laforest, M. (ed.), Autour de la narration. Les abords du récit conversationnel. Quebec: Éditions Nuit blanche, pp. 73-95.

LEJEUNE, P. (1975). Le Pacte autobiographique. Paris: Éditions du Seuil.

NÜNNING, A. (2010). “Narratologie ou narratologies?”. Translated by I. Vultur. In: Pier, J. \& Berthelot, F. (eds.), Narratologies contemporaines. Approches nouvelles pour la théorie et l'analyse du récit. Paris: Éditions des archives contemporaines, pp. 15-44.

PRINCE, G. (2006). "Narratologie classique et narratologie post-classique”. Vox Poetica. Online: http://www.vox-poetica.org/t/articles/prince.html.

PRINCE, G. (2010). "Périchronismes et temporalité narrative”. A Contrario 13, pp. 9-18. Online: https://www.cairn.info/revue-a-contrario-2010-1-page-9.htm.

QUENTIN, J. (ed..) (2014). Vérité de soi et quête de sens. Le récit de vie dans la relation de soin. Montreal: Liber.

REVAZ, F. (2008). “Expliquer et comprendre. Deux modes d'intelligibilité du réel”. In: Hudelot, C. et al. (eds.), L'Explication. Enjeux cognitifs et interactionnels. Leuven/Paris/Dudley, MA: Peeters, pp. 6573.

REVAZ, F. (2014). “Le récit suspendu, un genre narratif transmédial”. In: Monte, M. \& Philippe, G. (eds.), Genres et textes. Lyon: Presses universitaires de Lyon, pp. 117-134.

REVAZ, F. (2016). “La narrativité en sciences sociales : quelques pistes de réflexion”. Degrés 166167, p. a1-a17.

REVAZ, F. \& BAPST, L. (2014). "Récits et bribes de narrativité dans les consultations médicales : une approche discursive". Semen 37, pp. 59-73. Online: https://journals.openedition.org/semen/9878. RICCEUR, P. (1983). Temps et récit. T. I. Paris: Éditions du Seuil.

WHITE, M. \& EPSTON, D. (2003) [1990]. Les Moyens narratifs au service de la thérapie (Narrative Means to Therapeutic Ends) Translated from the English by J.-F. Bourse. Brussels: Satas.

\section{APPENDIXES}

\section{Transcription conventions}

...... pause (each dot equals a second)

: elongated syllable

- beginning of a word

/ significant rising intonation

$\backslash$ significant falling intonation

underlined overlapping words 
$<$ mhm $>$ backchannel

(laughter) expression of the speaker through mime and gesture

XXX uninterpretable segment

$\mathrm{M}^{*}$ anonymised name

\section{NOTES}

1. On narrative genres, see Adam, 2011.

2. We are talking here about so-called "classical" narratology, which originated in Russian formalism and developed through the achievements of structuralism. It includes structural analysis and its semiotic variant, both produced by French narratologists in the 1960s and 1970s.

3. On recent developments in narratology, see Baroni \& Revaz (2016).

4. It should be noted that post-classical narratology is in no way a new unified method and that it would certainly be more prudent to talk about "narratologies" in the plural since there currently exists a range of analytical models on which we can draw. On this point, see Nünning (2010).

5. By "situated" we mean that each speaker plays a specific role, in a given material, institutional and social context, which determines the nature and form of what is said.

6. On this point, Kafalenos (2006) suggests a method of analysis which, although based on a detailed analysis of narrative structure, places the emphasis on the reader's journey with its doubts, hypotheses, mistakes and adjustments.

7. This narrative turn is not unique to medicine. Already, at the end of the 19th century, historians engaged in a major epistemological debate on the role of narrative in setting out historical facts, pitting the advocates of a "comprehensive" approach against the advocates of an "explanatory" approach. On this point, see Revaz (2008).

8. With reference to this point, Jerome Bruner (2002, p. 78) said that "our culture is the source of the narratives that allow us to tell stories about ourselves, constantly weaving and reweaving the Self".

9. Although this premise is interesting, as we shall see below, the drawback of these therapies is that they usually suggest a working protocol for the therapist, which, in my opinion, makes the therapeutical approach too prescriptive.

10. In the 1950s, Schapp wrote a book devoted to the phenomenological analysis of narrative with the revealing title In Geschichten verstrickt, which can be translated as "Entangled in Stories".

11. All the examples in this paper are taken from video recordings of family psychotherapy sessions conducted by French child psychiatrist and psychoanalyst Pierre Benghozi in recent years. I would like to express to him my warmest thanks for making these recordings available to me.

12. One question that I consider to be as yet unresolved is how to describe this real-life neonarrative. Through the new narratives produced by family members? Through a confirmation by the psychiatrist of a change in the family economy? 
13. Concerning narrative and fragments of narrative in medical consultations, see Revaz \& Bapst (2014).

14. On serialisation, see Revaz (2014).

15. In sociology, a life story is based on an interview in which a researcher asks a person to talk about their life or some of their experiences. On this point, see Bertaux (1997).

16. The conventions applied to the transcriptions are listed in the annex.

17. On the subject of everyday narratives in a medical context, see Revaz \& Bapst (2014).

18. In psychoanalysis, the term "analysand" refers to a person who consults a psychoanalyst (the "analyst') in order to find answers to their difficulties.

19. This approach is part of the renowned "therapeutic alliance" described by Benghozi as follows: "During the session, I lend my support to the unfolding of the narrative reverie. I allow myself to be carried along by the flow of the story as it is constructed. I don't interpret what is said. I listen with empathic curiosity in order to support the emergence of a new narrative co-construction". (Comments made during a conversation in October 2017).

20. Between the two narrative versions, we can see that the object on which $\mathrm{Ma}^{*}$ is supposed to have impaled himself has changed: from the castle to the ship!

21. Note that in turn 5 , the therapist asks $M^{*}$ about her brother: "what did you do with him?" rather than "what happened?" The aim is clearly to encourage $\mathrm{M}^{*}$ to become involved in the story of Ma*'s fictitious death.

22. According to Thérèse Jeanneret (1999), coenunciation is the production of a discursive unit by at least two speakers. The production of a unit of meaning by several speakers can occur in two ways. Either L1 interrupts their turn of speaking with a syntactically incomplete statement, giving L2 the opportunity to complete it (coenunciation by "repair"), or L1 makes a statement that can be considered as syntactically complete, but that L2 will nevertheless expand by adding a new component (coenunciation by "addition").

23. So-called backchannel signals, whether based on gesture (smiles and nods) or word ("yes, yes", "mmm", etc.), let the speaker know that their message is received. On this point, see Laforest (1996).

24. To find out more about narration in social sciences, see Revaz, 2016.

\section{ABSTRACTS}

The narratives produced during psychotherapeutic interviews shake up a number of the received ideas posited by classical narratology on theories of self-narrative: retrospection, veracity, ordering and closure. In addition, the narratives produced by patients are rarely monologic; rather, they are co-built with other members of the family as well as with the therapist. Based on a recorded corpus of psychotherapeutic interviews, this paper will show that the emergence of 
narrative through interviews requires analytical tools that are able to describe not only the finished product that might emerge from a narrative but also the dynamic process of narrative construction with its fragments, incompleteness, hesitations and openness to the future.

Les récits produits lors d'entretiens psychothérapeutiques bousculent certaines idées-reçues véhiculées par les théories narratologiques classiques sur le récit de soi : la rétrospection, la véracité, la mise en ordre ou la clôture. De plus, les récits produits par les patients sont rarement monologiques; ils sont plutôt coconstruits avec les autres membres de la famille ainsi qu'avec le thérapeute. En prenant appui sur un corpus enregistré d'entretiens psychothérapeutiques, on montrera dans cet article que l'émergence de narrativité au fil des entretiens nécessite des outils d'analyse qui puissent rendre compte non seulement du produit fini que peut être un récit, mais aussi $\mathrm{du}$ processus dynamique du récit en train de se construire avec ses bribes, ses inachèvements, ses hésitations et ses ouvertures sur l'avenir.

INDEX

Mots-clés: narratologie classique, narratologie postclassique, psychothérapie, thérapie familiale, narration polylogale, coconstruction, coénonciation

Keywords: classical narratology, postclassical narratology, psychotherapy, family therapy, polylogal narrative, coconstruction, coenunciation

\section{AUTHORS}

\section{FRANÇOISE REVAZ}

Université de Fribourg, CH-1700 Fribourg, Suisse 